\title{
Export-led Industrialisation, Employment and Equity: The Malaysian Case
}

\author{
Prema-Chandra Athukorala and Jayant Menon
}

$\Gamma$

HE rapid and sustained growth of newly industrialising countries (NICs) in East Asia since the late 1960 s has been accompanied by a more equal income distribution than in other countries at a comparable stage of development. Mainstream (neoclassical) economists attribute this achievement to exportled industrialisation, which, given the right policies, can be replicated in other developing countries. The argument is that, as the comparative advantage of developing countries in international production is in relatively labour-intensive production, the expansion of manufactured exports translates into higher employment. As labour is the most widely distributed factor of production in the economy, employment expansion and the subsequent increase in real wages reduce poverty and income inequality (Krueger, 1995; Balassa \& Williamson, 1987; Fei et al., 1979).

Revisionist (structuralist) economists, however, doubt whether the NIC experience can be replicated in other developing countries (Amsden \& van der Hoeven, 1996; Helleiner, 1994; Taylor, 1991). These economists argue that 'growth with equity' was brought about largely by favourable initial conditions of these countries and highly accommodating world markets at the formative stage of their economic transformations. The NICs had higher educational standards, more even distribution of income, and broader-based wealth ownership than other developing countries, which helped establish a virtuous circle of high growth and low inequality. As well, the rapidly expanding markets in developed countries in the 1960s and early 1970s facilitated rapid expansion of labour-intensive manufactured exports without requiring real-wage restraint. If the NIC furms had been forced to operate in a depressed world market, so the revisionists argue, they would have been obliged to cut costs rather than to raise prices, leading to real wage stagnation and a massive shift of income from labour to capital (Amsden \& van der Hoeven, 1996).

This article seeks to shed light on this debate by examining the case of Malaysia, a country which has achieved impressively high growth through export-led industrialisation since the mid-1980s. Malaysia's initial conditions and structural characteristics had more in common with the many other developing countries in the region than with the East Asian NICs. Thus, the lessons from the Malaysian experi-

Prema-Chandra Athukorala is Senior Fellow in the Research School of Pacific and Asian Studies at The Australian National University. Jayant Menon is Senior Research Fellow at the Centre of Policy Studies and Impact Project at Monash University. 
ence would be relevant to the debate on trade and industrial policy reforms in developing countries.

\section{Post-Independence Economic Policy}

At independence (Merdeka) in 1957, economic conditions in Malaysia (then the Federation of Malaya) appeared favourable. But the country had to face the challenge of a plural society inherited from the colonial past. At the time, the native Malays, who accounted for 52 per cent of the population, dominated politics, but were relatively poor, being involved mostly in low-productive agricultural activities. The ethnic Chinese ( 37 per cent of the population) enjoyed greater economic power and dominated most of the modern-sector activities, but lacked the ethnic solidarity or political power of the Malays. Economic policy-making in postindependence Malaysia therefore became a continuing struggle to promote development while preserving communal harmony and political stability.

During the first decade of independence, the government continued the colonial open-door policy stance to trade and industry, while attempting to redress ethnic and regional economic imbalances through rural development schemes and the provision of social and physical infrastructure. Like many other developing countries at this time, Malaysia sought industrialisation through import-substitution policies. However, unlike other countries, Malaysia eschewed forced industrialisation through high tariffs and quantitative import restrictions and the establishment of state-owned industrial enterprises ( $\mathrm{Lim}, 1992)$. Foreign investment was welcomed during this period. But its impact on the economy was limited for two reasons: (i) in the absence of binding import restrictions, there was no compelling reason for foreign producers to establish import-substituting plants in Malaysia; and (ii) the internationalisation of production within vertically integrated global industries had not yet begun.

By the late 1960s, it was clear that future industrial development depended upon the expansion of export-oriented industries. Incentives offered to exportoriented ventures under the Industrial Incentives Act 1968 included exemptions from company tax and duty on imported inputs, relief from payroll tax, investment tax credits and accelerated depreciation allowances on investment.

Economic expansion during 1957-69, though respectable, failed to make a substantial contribution towards solving the 'special' problems of the Malays. On the other hand, with urban unemployment rising and education and language again looming as issues, non-Malays began to question the extent to which their interests were being safeguarded in the new Malaysia. The bloody communal riots of May 1969 resulted in a clear shift from policy-making based purely on economic considerations and towards a policy of affirmative action based on ethnicity. This New Economic Policy (NEP) formed the basis of the Second Malaysia Plan (1971-75).

\footnotetext{
1 In 1957-58, 34.9 per cent of households had incomes of less than RM120 (A\$48) a month (the official cut-off point for measuring poverty). More than half of these households were Malay, and more than two-thirds were rural (Snodgrass, 1980).
} 


\section{The New Economic Policy}

The objective of the NEP was to maintain national unity by eradicating poverty through employment generation and by restructuring society so as to eliminate the identification of race with economic function. To achieve the first objective, development strategy focused on export-oriented industrialisation and an ambitious rural and urban development program. The Free Trade Zone (FTZ) Act 1971 enticed exportoriented foreign direct investment with incentives such as duty-free imports of raw material and capital equipment, streamlined customs formalities, subsidised infrastructure facilities and company income-tax incentives. For the second objective, long-term targets were established for Bumiputra (ethnic Malay) ownership of share capital in limited companies, and for the proportion of Malays employed in manufacturing and occupying managerial positions. The NEP aimed to increase the Malay share in corporate assets from 2 per cent in 1970 to 30 per cent in 1990, and to make employment patterns in the urban sector reflect the racial composition of the country. Malay participation in business was promoted in two ways. First, the public sector, where Malays held most of the key positions, was expanded, by setting up new ventures and by the purchase of foreign-owned businesses. Second, Malays were granted privileged access to share ownership and business opportunities in the private sector. The Industrial Coordination Act (ICA) 1975 strengthened measures to implement NEP norms on Bumiputra participation at the enterprise level. Under the ICA, the conduct of medium- and large-scale enterprises was subject to licensing with the aim of improving the relative position of the Malays in the modern sector of the economy.

The promotion of heavy industries was a key element in the Fourth Five-Year Plan (1981-85). The Heavy Industries Corporation of Malaysia (HICOM), a publicsector holding company, was formed in 1980 to go into partnership with foreign companies in setting up industries in areas such as petrochemicals; iron and steel; cement; paper and paper products; machinery and equipment; general engineering; transport equipment; and building materials. These industries were expected to 'strengthen the foundation of the manufacturing sector ... [by providing] strong forward and backward linkages for the development of other industries' (Government of Malaysia, 1984:271). Even though the new selective industrialisation push was often rationalised as an attempt to emulate Japan and Korea (hence the 'look East' policy, a term coined by Mahathir Mohamed in 1981), in practice the selection of new projects was based largely on traditional import-substitution criteria. These projects were supported with subsidised credit, government procurement provisions and heavy tariff protection, without subjecting them to any market-based performance norms. By 1987, Malaysia had 867 corporate public enterprises, more than a third of which were in manufacturing.

The blow-out in public expenditure caused largely by the heavy industries policy led to widening budget and current account deficits, and an increase in external debt from about 1981. As well, the world economic recession in the mid-1980s caused a significant fall in the prices of tin and palm oil and depressed demand for fledgling manufactured exports (in particular electronics) (Corden, 1993:35). The required cuts in government expenditure had contractionary effects on the domestic econ- 
omy. At the same time, the uncertainty in the policy environment was reflected in stagnation in private investment (both local and foreign) in the economy. These factors brought the economic advances of the 1970s to a halt and increased racial tensions. Subsequent policy reforms placed greater emphasis on the role of the private sector and strengthening the conditions for export-oriented growth.

\section{The National Development Policy}

In 1986 the government declared the NEP to be 'in abeyance'. The Promotion of Investment Act passed in the same year introduced fresh, more generous incentives for private investors; some of the ethnic requirements of the NEP were relaxed; and up to 100 per cent foreign-equity ownership of export-oriented companies was allowed. Work permit requirements for foreign employees of companies with foreign paid-up capital of US $\$ 2 \mathrm{~m}$ or more were eased. The NEP was subsequently replaced (in 1990) with the National Development Policy (NDP), which aimed to redress racial imbalances in a more overt manner through initiatives geared to entrepreneurship, managerial expertise and skills development within the Malay community.

Since the mid-1980s, state-owned enterprises have been gradually privatised and restructured; by the early 1990s, state ownership in manufacturing was limited to some politically sensitive ventures in automobile manufacturing and to the petrochemical, iron and steel and cement industries. Tariff protection to domestic manufacturing, which had always been lower than in other developing countries, was further reduced, the effective rate falling from 31 per cent in 1979-80 to 17 per cent by the late 1980s (Salleh \& Meyanathan, 1993:12). These reforms were accompanied by a strong focus on macroeconomic stability (including the maintenance of a realistic real exchange rate), and meeting the infrastructure needs of a rapidly expanding economy. The Fifth (1986-90) and Sixth (1991-95) Malaysia Plans saw a significant reduction in overall government expenditure and a shift in government spending away from public-sector enterprises and towards infrastructure projects designed to enhance private-sector development.

In the labour market there was a new emphasis (like that of the East Asian NICs) on job creation rather than the protection of workers' rights through labour legislation. Labour market flexibility was promoted through compulsory arbitration of disputes and bans on the right to strike in 'essential services'. Furthermore, unions were banned in the most important export-oriented industry - electronics until 1988, after which only 'in-house' unions were allowed at the plant, rather than the industry, level. This policy, despite its many critics, has certainly facilitated the outward-oriented growth process with foreign capital participation.

\footnotetext{
${ }^{2}$ For a lucid discussion of Malaysia's political changes as they relate to the industrialisation process, see Crouch (1996:Ch. 12).
} 


\section{Growth and Structural Change}

The data on overall economic growth and export orientation of the Malaysian economy are summarised in Table 1. Annual growth during 1965-86 averaged a respectable 5.5 per cent. However, this performance record was uneven, reflecting the impact of primary commodity cycles and changes in government expenditure. Growth of real GNP averaged about 6.5 per cent per annum during the 1970s, but then slowed down in the first half of the 1980 s, falling to negative 1 per cent in 1985. With better domestic macroeconomic policies and market-based reforms, the Malaysian economy has picked up again since 1987. Real GDP growth accelerated to over 8 per cent a year on average over the nine years up to 1995. This outstanding economic performance was achieved in a lacklustre world economic environment.

The data point to a close association between growth acceleration and the degree of export orientation of the economy. The export-GDP ratio increased at a modest rate during the 1970 s, slowed in the first half of the 1980 s and then increased sharply from about 1987. The export-GDP ratio in 1995 (96 per cent) was twice as high as in 1970 .

In the 1970 s and early 1980 s, Malaysian economic growth stemmed largely from the expansion of service industries flowing from public sector activities and growth in primary production. In the primary sector, growth in the 1970 s was led by a rapidly expanding palm oil sector, and modestly expanding rubber production. In the deregulated environment since the late 1980 s, not only has growth significantly increased, but much of it is has come from the expansion of manufacturing through private sector initiatives. In 1989, the manufacturing share in GDP for the first time overtook that of agriculture. Between 1987 and 1995, over 50 per cent of the growth in GDP flowed directly from the manufacturing sector, which expanded by an average annual rate of 14.5 per cent and increased its share of GDP from about 20 per cent to over 33 per cent. In addition, much of the output and expansion in the tertiary (service) sectors in recent years has been closely related to the expansion of the manufacturing sector (Ariff, 1991).

The expansion of manufacturing production has predominantly been exportled. In the early 1970s, the share of manufactures in total merchandise exports was about 10 per cent. But in 1980-95, manufactured exports grew (in current US dollar terms) at an annual compound rate of 35 per cent. In 1994, with a manufacturing share of about 78 per cent, Malaysia was the developing world's sixth largest exporter of manufactures, after the four East Asian NICs and China. The share of exports in gross manufacturing output had grown to over 60 per cent by the early 1990s, up from less than 10 per cent in the early $1970 \mathrm{~s}$. In the $1970 \mathrm{~s}$, resource-based manufacturing such as food, beverages, tobacco, wood products and basic metals loomed large in the structure of manufactured exports. The transformation of the export structure in line with emerging patterns of the international division of labour gathered momentum in the late 1980s. At first, Malaysia found market niches in simple assembly operations in electronics and electrical goods, and production of diffused-technology 
consumer goods. In recent years, the export composition has begun to diversify into mature-technology final products such as radios, televisions, cameras and computers.

Table 1

Malaysia: growth and export orientation, 1970-95

\begin{tabular}{|c|c|c|c|c|c|}
\hline \multirow{2}{*}{ Year } & \multicolumn{2}{|c|}{ GDP } & \multicolumn{2}{|c|}{ Per-capita GDP } & \multirow{2}{*}{$\begin{array}{c}\text { Export } \\
\text { orientation } \\
\text { Exports/ } \\
\text { GDP } \\
(\%)\end{array}$} \\
\hline & $\begin{array}{c}\text { value } \\
\text { (millions of } \\
\text { ringgit) }\end{array}$ & $\begin{array}{c}\text { growth } \\
\text { (\%) }\end{array}$ & $\begin{array}{l}\text { value* } \\
\text { (ringgit) }\end{array}$ & $\begin{array}{l}\text { growth } \\
\text { (\%) }\end{array}$ & \\
\hline $1965-69$ & 30,149 & 7.08 & 2,902 & 3.97 & 46.09 \\
\hline $1970-74$ & 35,986 & 9.12 & 3,257 & 6.04 & 42.30 \\
\hline $1975-79$ & 51,703 & 7.22 & 4,734 & 4.17 & 50.44 \\
\hline 1980 & 64,883 & 7.44 & 4,736 & 5.48 & 57.54 \\
\hline 1981 & 69,387 & 6.94 & 4,918 & 3.83 & 52.34 \\
\hline 1982 & 73,509 & 5.94 & 5,066 & 3.02 & 50.89 \\
\hline 1983 & 78,104 & 6.25 & 5,245 & 3.54 & 51.18 \\
\hline 1984 & 84,116 & 7.70 & 5,509 & 5.02 & 54.27 \\
\hline 1985 & 83,305 & -0.96 & 5,313 & -3.55 & 54.85 \\
\hline 1986 & 84,179 & 1.05 & 5,225 & -1.65 & 56.31 \\
\hline 1987 & 88,717 & 5.39 & 5,367 & 2.71 & 63.85 \\
\hline 1988 & 96,647 & 8.94 & 5,705 & 6.30 & 67.61 \\
\hline 1989 & 105,547 & 9.21 & 6,083 & 6.63 & 73.26 \\
\hline 1990 & 115,828 & 9.74 & 6,522 & 7.21 & 76.28 \\
\hline 1991 & 125,861 & 8.66 & 6,923 & 6.15 & 80.84 \\
\hline 1992 & 135,667 & 7.79 & 7,290 & 5.30 & 77.65 \\
\hline 1993 & 146,987 & 8.34 & 7,636 & 4.74 & 81.45 \\
\hline 1994 & 159,848 & 8.75 & 7,972 & 4.41 & 89.82 \\
\hline 1995 & 175,225 & 9.62 & 8,506 & 6.70 & 95.50 \\
\hline
\end{tabular}

*Constant (1990) prices.

Source: International Monetary Fund, Intemational Financial Statistics Yearbook - 1995 (Washington DC) and Malaysian Ministry of Finance, Economic Report 1995 (for estimates for 1995).

Foreign direct investment (FDI), the engine of manufactured export expansion, has grown remarkably over the past two decades, increasing almost ten-fold between 1987 and 1991. Since the mid-1980s, FDI flows to Malaysia have been increasing at a faster rate than those to the other ASEAN countries, and, since 1991, have exceeded such flows to any of the other ASEAN countries. By the late-1980s, FDI inflows had shifted from production for the domestic market to using Malaysia as a base for

\footnotetext{
${ }^{3}$ The Malaysian experience with attracting FDI has been discussed in detail elsewhere by Athukorala and Menon (1995).
} 
manufacturing for the global market. The share of projects with an export orientation of 50 per cent or more increased from 24 per cent of total approved projects in 198485 to about 82 per cent by $1988-89$. The proportion of projects with an export orientation of 80 per cent or above increased from one-fifth of the total in 1984 to about three-quarters in 1989. There are no direct estimates of the share of foreign firms in exports. However, a simple comparison of data on export and output shares of foreign firms shows that they provided over threc-quarters of total manufactured exports by the mid-1990s (Lall, 1995). There is a close association between the degree of foreign presence in product sectors and their relative contribution to total manufactured exports (Athukorala \& Menon, 1996). The electronics industry (which is almost completely foreign-owned) alone contributed over 63 per cent of total exports in 1994. Since the early 1980s, Malaysia has been the largest developing-country exporter (and one of the world's major exporters) of electronic components, particularly integrated circuits.

There is little evidence that either the government leadership in industrial policy in general or the heavy industrialisation push in the early 1980s in particular has affected the export-led industrialisation process. The structure of industry that has evolved over the past two decades closely reflects Malaysia's comparative advantages and changing factor endowment. Most of the industries set up under HICOM were 'born losers' which were artificially spawned with subsidies (Chee, 1994:249). By the late 1980s, HICOM had invested over RM42 billion in various projects which generated fewer than 5,000 jobs directly (RM400,000 per job), and exports from these industries were almost negligible (Chee, 1994:Table 10.5). Doubtless, some employment, some technical and managerial skills and scale economies have been generated, but at considerable expense. Apart from the direct economic cost, inefficient heavy industry projects (mostly in investment and intermediate goods industries) were a burden on downstream industries, which were forced to pay higher prices for the protected products.

\section{Employment and Equity}

Unemployment emerged as a public issue in Malaysia only in the early 1960s. In 1963 the unemployment rate in Peninsular Malaysia was estimated at 6 per cent. By the time the NEP was promulgated in 1970, this had increased to 8 per cent, but the Second Malaysia Plan could offer no more than containment at that level (Snodgrass, 1980:59). After dropping to around 5 per cent in the early 1980s, the unemployment rate rose to a peak of 8.3 per cent in the depth of the recession in 1986. Thereafter, it began to decline, falling to only 2.8 per cent by 1995 (see Figure 1). This impressive employment record has been achieved in the context of rising labour force participation of the population, from an average level of 65 per cent in $1980-85$ to over 67 per cent by the mid $1990 \mathrm{~s}$. This latter increase is a reflection of both the rapid rate of urbanisation and the increased labour-force participation of women, which reached about 47 per cent in the mid-1990s, up from 44 per cent in the early $1980 \mathrm{~s}$. 


\section{Figure 1}

\section{Unemployment rate, 1980-96}

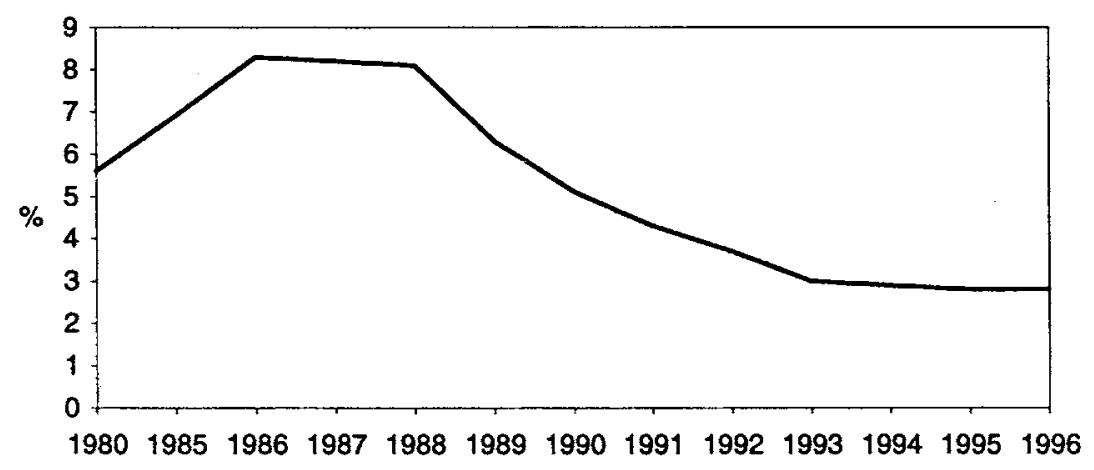

Note: 1996 , forecast.

Source: Malaysian Ministry of Finance, Economic Report (various issues).

Most of the new employment has come from the expansion of the manufacturing sector (Table 2). The share of manufacturing in total labour deployment in the economy increased from 14 per cent in the mid-1970s to over 25 per cent by the mid-1990s. The direct contribution of manufacturing to total employment increment between 1987 and 1994 was as high as 60 per cent, amounting to an additional $1.2 \mathrm{~m}$ jobs. In addition, as noted, much of output (and hence employment) expansion in the tertiary (service) sectors in recent years has been closely related to the expansion of the manufacturing sector. The data reported in Athukorala and Menon (1996) point to the important role played by export-oriented foreign investment to manufacturing employment. The percentage of workers employed in foreign firms increased from about 30 per cent in 1983 to 42 per cent in 1992 . The increase in the employment share was much faster than the increase in the share of output of these firms (from 41 to 48 per cent), suggesting that, with the rapid expansion of export-oriented manufacturing, the structure of manufacturing production has become more labour-intensive over the years. This pattern was particularly noticeable in nonmetallic minerals, basic metal products, fabricated metal products and miscellaneous manufacturing. In the case of electronics, the employment and output shares have remained virtually unchanged at comparable levels as this industry has been highly labour-intensive right from the start.

Real wages in the manufacturing sector declined in the early 1970 s (see Table 3). At the time, critics of the export-led industrialisation strategy claimed that the working class was subject to high 'disciplines' (through restrictions on labour unions) and low wages for the benefit of multinationals and local capitalists (Jomo \& Osman-Rani, 1984). But this pessimistic view was refuted by subsequent developments. 


\section{Table 2}

\section{Employment by sector, 1976-95 (\% shares)}

\begin{tabular}{|lccccc|}
\hline \multicolumn{1}{c}{ Sector } & 1976 & 1980 & 1985 & 1990 & 1995 \\
\hline Agriculture, forestry and fishing & 43.6 & 40.6 & 31.3 & 29.9 & 18.9 \\
Industry & 20.9 & 22.7 & 23.6 & 24.6 & 34.9 \\
Manufacturing & 14.2 & 15.8 & 15.2 & 17.6 & 25.5 \\
Services & 35.5 & 36.7 & 45.1 & 45.5 & 46.2 \\
Total & 100 & 100 & 100 & 100 & 100 \\
('000) & 4,376 & 4,817 & 5,622 & 6,682 & 8,060 \\
\hline
\end{tabular}

Source: Malaysian Ministry of Finance, Economic Report (various issues).

The decline in real wages in the early 1970s partly reflected the shift in the structure of production away from capital-intensive import substitution activities towards labour-intensive export production. At the same time, real wages were kept low by the availability of a vast pool of surplus labour in the economy, particularly from the rural sector. With the gradual absorption of surplus labour in exportoriented industries, real wages started to rise from the late $1970 \mathrm{~s}$, and reached a historical high of 110 in 1992 . The significant decline in the unemployment rate suggests that real wages would have continued to increase during the ensuing years. Interestingly, the recent increases in real wages have occurred even though the profitability of manufacturing production (as measured by the price-cost margin) remained virtually unchanged (Table 3). 'Thus, it appears that with the rapid depletion of surplus labour reserves in the economy, workers have become the major beneficiaries of productivity growth in manufacturing. Higher productivity, rather than lower wages, seems to have borne the burden of creating competitiveness. In the absence of minimum-wage legislation, employment levels have risen first followed by market- and productivity-driven increases in real wage levels.

Growth in real wages in the 1990s would have presumably been much greater but for the influx of migrant workers. As the domestic labour market approached full employment, forcing rapid increases in real wages, a massive inflow of migrant workers occurred from neighbouring labour surplus countries, in particular Indonesia. Official estimates put the number of migrant workers in Malaysia at half a million in 1994. However, there is circumstantial evidence that the number could be as high as 2 million (about 16 per cent of the workforce). By the early 1990s, more than half of the workforce in the construction industry and the plantation sector consisted of foreign workers, by which time they had also begun to enter the manufacturing sector.

The impact of various government programs on reducing poverty and income inequalities during the first three decades of the post-independence period were limited. The ethnic and rural-urban distribution of poverty and income inequality had hardly changed over the period. By the late 1980 s, 88 per cent of poor house- 
holds were rural, and almost 60 per cent of rural households were poor (Anand, 1983).

\section{Table 3}

\section{Employment, profitability and real wages in the manufacturing sector, 1965-94}

\begin{tabular}{|c|c|c|c|c|}
\hline & $\begin{array}{c}\text { Employment } \\
(1990=100)\end{array}$ & $\begin{array}{l}\text { Proe cost } \\
\text { margin }(\%)\end{array}$ & $\begin{array}{l}\text { Real value added } \\
\text { per worker } \\
(1990=100)\end{array}$ & $\begin{array}{l}\text { Real Wages } \\
(1990=100)\end{array}$ \\
\hline $1965-69$ & 12.1 & 17.3 & 57.1 & 67.6 \\
\hline $1970-74$ & 24.9 & 21.5 & 64.0 & 61.6 \\
\hline $1975-79$ & 53.4 & 20.3 & 67.5 & 74.2 \\
\hline 1980 & na & na & na & na \\
\hline 1981 & 58.2 & 17.3 & 73.6 & 82.5 \\
\hline 1982 & 61.7 & 16.6 & 71.8 & 86.4 \\
\hline 1983 & 54.8 & 17.9 & 82.6 & 93.0 \\
\hline 1984 & 59.2 & 19.0 & 89.9 & 97.6 \\
\hline 1985 & 56.3 & 18.6 & 94.1 & 105.2 \\
\hline $1986^{\circ}$ & 56.8 & 20.1 & 102.8 & 104.1 \\
\hline 1987 & 61.4 & 18.6 & 98.6 & 102.4 \\
\hline 1988 & 71.0 & 18.1 & 99.5 & 98.7 \\
\hline 1989 & 82.7 & 18.9 & 104.5 & 99.4 \\
\hline 1990 & 100 & 18.6 & 100 & 100 \\
\hline 1991 & 115.8 & 18.9 & 106.7 & 104.4 \\
\hline 1992 & 122.5 & 18.8 & 107.3 & 108.3 \\
\hline 1993 & 139.9 & na & na & 109.7 \\
\hline 1994 & 152.6 & na & na & 112.9 \\
\hline
\end{tabular}

Sources: Compiled from Malaysian Department of Statistics, Annual Survey of Manufacturing and Monthly Bulletin of Manufacturing Statistics (for 1993 and 1994).

Since the mid-1980s, Malaysia's record of reducing absolute poverty has been impressive (Table 4). The incidence of poverty among all households (as measured by the percentage of total households below the poverty line) has fallen from 18.4 per cent in 1984 to 9.6 per cent in 1995; this figure is projected to fall to 6.0 per cent by 2000 (see Snodgrass, 1995). A significant decline in poverty is observable for both urban and rural households, even though the incidence of poverty is still relatively high in rural areas. According to the Human Development Index of the United Nations, Malaysia ranked fourth (after Saudi Arabia, South Korea and Mauritius) in the world in terms of improvement in living standards between 1970 and 1990 (Snodgrass, 1995). All ethnic groups have shared in the remarkable improvement in quality of life (Yusof, 1994). 


\section{Table 4}

\section{Incidence of poverty and hard-core poverty by region, and Gini coefficients, $1970-1995$ and forecast for 2000}

\begin{tabular}{|lcccccc|}
\cline { 2 - 6 } \multicolumn{1}{c}{} & 1970 & 1984 & 1990 & 1993 & 1995 & 2000 \\
\hline Incidence of poverty & & & & & & \\
$\quad$ Urban & 0.255 & 0.082 & 0.075 & 0.053 & 0.041 & 0.022 \\
$\quad$ Rural & 0.586 & 0.247 & 0.218 & 0.186 & 0.161 & 0.110 \\
$\quad$ Total & 0.493 & 0.184 & 0.171 & 0.135 & 0.096 & 0.060 \\
$\begin{array}{l}\text { Incidence of hard-core } \\
\text { poverty }\end{array}$ & & & & & & \\
$\quad$ Urban & & & & & & \\
Rural & 0.158 & 0.024 & 0.014 & 0.011 & 0.009 & 0.010 \\
$\quad$ Total & 0.446 & 0.087 & 0.052 & 0.043 & 0.037 & 0.001 \\
Gini coefficient & na & 0.063 & 0.040 & 0.030 & 0.022 & 0.005 \\
& 0.537 & 0.479 & 0.446 & 0.459 & 0.464 & na \\
\hline
\end{tabular}

* The cut-off income level for the determination of hard-core poverty is set at half of that used in defining poverty, which varies from year to year (refer to source documents listed below).

Sources: Anand (1983); Government of Malaysia (1989, 1991, 1993 and 1996).

Table 5

Mean monthly household gross incomes by ethnic group, 1957-95

\begin{tabular}{|ccccccc|}
\hline Group & $1957 / 58$ & $1967 / 68$ & 1970 & 1984 & 1990 & 1995 \\
\hline All groups & 199 & 217 & 264 & 1,095 & 1,167 & 2,007 \\
Malay & 144 & 130 & 172 & 852 & 940 & 1,600 \\
& $(100)$ & $(100)$ & $(100)$ & $(100)$ & $(100)$ & $(100)$ \\
Chinese & 272 & 321 & 394 & 1,502 & 1,631 & 2,895 \\
& $(189)$ & $(247)$ & $(229)$ & $(176)$ & $(170)$ & $(181)$ \\
Indian & 217 & 253 & 304 & 1,094 & 1,209 & 2,153 \\
& $(151)$ & $(195)$ & $(175)$ & $(128)$ & $(128)$ & $(135)$ \\
\hline
\end{tabular}

Notes: Figures in parentheses indicate group incomes as \% of Malay incomes. All other figures are in Ringgit. " Includes minorities and non-citizens.

Sources: For 1957-70: Anand (1983); for 1984: Government of Malaysia (1989); for 1990 and 1995: Government of Malaysia (1996).

The reduction in poverty and increase in overall living standards stem mainly from the growing opportunities for non-agricultural work, particularly in the rapidly expanding export-oriented manufacturing industries. Since unskilled labour is the most widely distributed factor of production, the increase in its real wage has brought about an overall reduction in poverty in the country. In addition, the increase in the number of two-income households has contributed to the increase in 
total household income. This is underpinned by the increasing importance of women in the work force. Again, much of this increase is due to the demand for low-skilled labour generated by the rapid expansion of labour-intensive exportoriented manufacturing activities. In sum, employment generation and poverty reduction in Malaysia since the late 1980 s compares closely to that of Korea and Taiwan in the late 1970s and 1980s (Fei et al., 1979; Hong, 1990).

Though less so than in reducing absolute poverty, Malaysia has been successful (by the standard of developing countries at the same stage of economic development) in addressing inequality in the size distribution of income. Between 1970 and 1990, the Gini coefficient fell sharply from 0.537 to 0.446 (Table 4). True, it rose slightly to 0.464 in 1995 . The overall trend, however, suggests that the benefits of rapid growth in Malaysia have been distributed reasonably widely. The relative position of Malay households improved notably in terms of mean household income between the mid-1960s and 1990 (Table 5). The data for 1995 indicate a slight worsening of the relative position of Malay households. The disaggregated data suggest that this has been due mainly to differential growth rates of incomes in the top 20 per cent and the bottom 40 per cent of households. Within the middle 40 per cent of households the relative position of Malays has remained virtually unchanged (Government of Malaysia, 1996:89). ${ }^{5}$ Income inequality, in terms of both size distribution and race, remains an issue in Malaysia. But, because of the remarkable increase in living standards across the board, it is a less politically sensitive issue than it once was.

\section{Concluding Remarks}

Malaysia is undoubtedly a development success story. Its achievements have been especially remarkable since the late 1980 s when economic policy decisively adopted an outward orientation. Economic growth during this period has been accompanied by rising living standards and an improvement in the distribution of income, ameliorating the twin problems of poverty and racial income imbalances.

Malaysia's economic success can be attributed to its ability to place itself within a new world economic order that is characterised by increased internationalisation of production. As a small and open economy, Malaysia's economic policy stance has been to respond to developments on the international front as they unfolded. Despite some policy excesses triggered by conflicting objectives in a plural society, the policy-makers have been successful in rectifying policy errors swiftly.

The Malaysian experience of growth with equity is consistent with the mainstream (neoclassical) policy stance relating to export-led industrialisation. The Ma-

\footnotetext{
${ }^{4}$ The labour force participation rate for women increased from 37.2 per cent in 1970 to 45.8 per cent in 1990 and 47.1 per cent in 1995, while the share of women in employment increased from less than 30 per cent in 1970 to 31.4 per cent in 1990 and 33.7 per cent in 1995 (Government of Malaysia, 1991, 1996).

${ }^{5}$ These compositional shifts do suggest, however, that income distribution within the Malay community may have worsened (see Shari \& $\mathrm{Zin}, 1990$ ).
} 
laysian experience shows that, in a small and open economy, the task of achieving the apparently conflicting objectives of growth and equity is facilitated by a long-term commitment to an open and liberal trade and investment policy regime. Unlike many other developing countries, Malaysia never resorted to stringent quantitative trade restrictions. Domestic price signals were therefore never insulated from world market conditions, and resource costs arising from rent-seeking activities have always been minimal by developing country standards. Despite the affirmative action policies under the NEP, the private sector was never marginalised and the policy emphasis on export orientation was never compromised. This policy regime, coupled with a stable political climate, has enabled the Malaysian economy to take full advantage of the new opportunities arising from integration with the global economy. There is little doubt that the affirmative action program was instrumental in legitimising government policy and achieving political stability and social harmony. It was an effective and explicit mechanism demonstrating that all would share in future growth. At the same time, the resource cost of these direct redistributional policies was not a serious impediment to growth because of the key role played by FDI flows and rapid export expansion in augmenting the domestic resource base.

\section{References}

Amsden, A. \& R. van der Hoeven (1996), 'Manufacturing Output, Employment and Real Wages in the 1980s: Labour's Loss Until the Century's End', Journal of Development Studies 32(4): 50630 .

Anand, S. (1983), Inequality and Poverty in Malaysia: Measurement and Decomposition, Oxford University Press for the World Bank, Washington DC.

Ariff, M. (1991), The Malaysian Economy: Pacific Connections, Oxford University Press, Kuala Lumpur.

Athukorala, P. \& J. Menon (1995), 'Developing with Foreign Investment: Malaysia', Australian Economic Review 109: 9-22.

(1996), 'Foreign Direct Investment and Industrialisation in Malaysia: Exports, Employment and Spillovers', Asian Economic Journal 10(1): 29-44.

Balassa, B. \& J. Williamson (1987), Adjusting to Success: Balance of Payments Policy in the East Asian NICs, Institute for International Economics, Washington DC.

Chee Peng Lim (1994), 'Heavy Industrialisation: A Second Round of Import Substitution', pp. 24462 in K. Jomo (ed.), Japan and Malaysian Development in the Shadow of the Rising Sun, Routledge, London.

Corden, M. (1993), 'Managing the Macroeconomy', background paper for the World Bank's East Asian Miracle Study, Washington DC. (Johns Hopkins University mimeo).

Crouch, H. (1996), Government and Society in Malaysia, Allen \& Unwin, Sydney.

Fei, J., G. Ranis \& S. Kuo (1979), Growth with Equity: The Tawan Case, Oxford University Press, New York.

Government of Malaysia (1984), Mid-term Review of the Fourth Malaysia Plan 1981-1985, National Printing Department, Kuala Lumpur.

(1989), Mid-term Review of the Fifth Malaysia Plan 1986-1990, National Printing Department, Kuala Lumpur. 
_ (1991), Sixth Malaysia Plan 1991-1995, National Printing Department, Kuala Lumpur.

- (1993), Mid-term Review of the Sixth Malaysia Plan 1991-1995, National Printing Department, Kuala Lumpur.

- (1996), Seventh Malaysia Plan 1996-2000, National Printing Department, Kuala Lumpur.

Helleiner, G. (1994), 'Introduction', in G. Helleiner (ed.), Trade Policy and Industrialization in Turbulent Times, Routledge, London.

Hong, W. (1990), 'Export-Oriented Growth of Korea: A Possible Path to Advanced Economy', International Economic Joumal 4(2): 1-24.

Jomo, K. \& H. Osman-Rani (1984), 'Wage Trends in Peninsular Malaysia Manufacturing, 1963-1973', Kajian Ekonomi Malaysia 21 (1): 18-38.

Krueger, A. (1995), "The Role of Trade in Growth and Development: Theory and Lessons from the East Asian Experience', pp. 1-10 in R. Garnaut, E. Grilli \& J. Riedel (eds), Sustaining Export-Oriented Development Ideas from East Asia, Cambridge University Press, Cambridge.

Lall, S. (1995), 'Malaysia: Industrial Success and the Role of the Government', Journal of International Development 7(5): 759-74.

Lim, D. (1992), 'Dynamics of Economic Policy Making: A Study of Malaysian Trade Policies and Performance', pp. 94-114 in A. MacIntyre \& K. Jayasuriya (eds), The Dynamics of Economic Policy Reforms in Asia and South-west Pacific, Oxford University Press, Singapore.

Salleh, I. \& S. Meyanathan (1993), Malaysia: Growth, Equity, and Structural Transformation, The Lessons of East Asia, World Bank, Washington DC.

Shari, I. \& R. Zin (1990) 'The Patterns and Trends of Income Distribution in Malaysia', Singapore Economic Review 35(1): 102-23.

Snodgrass, D. (1980), Inequality and Economic Development in Malaysia, Oxford University Press, Kuala Lumpur.

- (1995), Successful Economic Development in a Multiethnic Society: The Malaysian Case, Harvard Institute for International Development, Cambridge, Mass.

Taylor, L. (1991), 'Economic Openness: Problems to the Century's End', pp. 99-147 in T. Baruni (ed.), Economic Liberalisation No Panacea: The Experience of Latin America and Asia, Clarendon Press, Oxford.

Yusof, Z. (1994), 'Growth and Equity in Malaysia', pp. 591-615 in Malaysian Development Expenience: Changes and Challenges, National Institute of Public Administration, Kuala Lumpur.

We thank Hal Hill, Harold Crouch, Sisira Jayasuriya, two anonymous referees and the participants of the 20th Anniversary Conference of the Asian Studies Association of Australasia (La Trobe University) and the Trade and Development Seminar (Research School of Pacific and Asian Studies, The Australian National University) for comments. We are grateful to Mohamed Ariff and the Faculty of Economics and Administration, The University of Malaya, for institutional support to conduct field research in Malaysia. 